\title{
ARTICLE
}

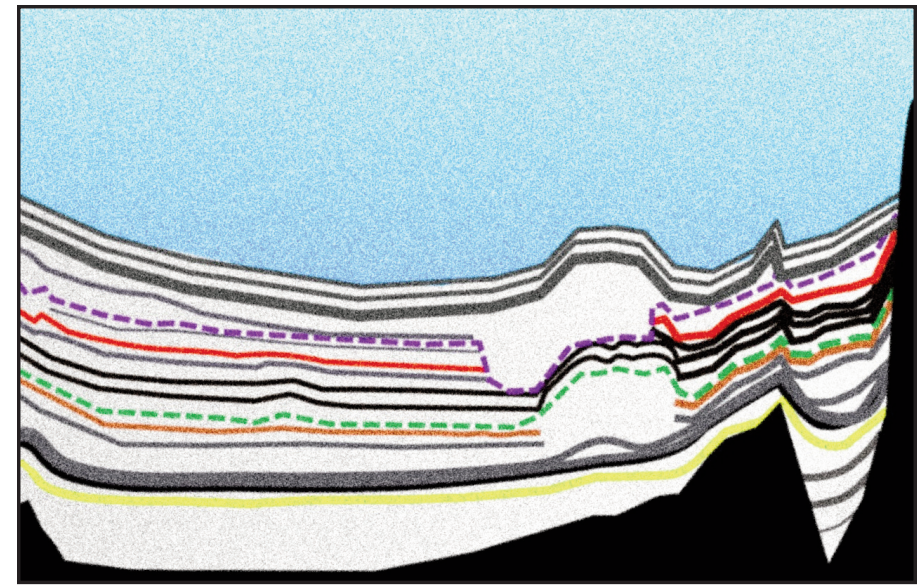

\section{An Integrated Stratigraphic Approach to Investigating Evidence of Paleoearthquakes in Lake Deposits of Eastern Canada}

\author{
Gregory R. Brooks \\ Geological Survey of Canada \\ Natural Resources Canada \\ 601 Booth Street \\ Ottawa, Ontario, K1 A OE8, Canada \\ E-mail:greg.brooks@NRCan-RNCan.gc.ca
}

\section{SUMMARY}

Seismic shaking can generate mass movements, turbidites, and soft-sediment deformation within lake basins. These 'disturbed' deposits may be preserved, and provide a stratigraphic record of paleoearthquakes. A three-dimensional seismostratigraphy of the lake deposits can be constructed from a high-density, sub-bottom acoustic profile (SAP) survey, allowing disturbed deposits within the basin to be identified and mapped. Event layers composed of one or more disturbed deposits can be identified within the seismo-stratigraphy, and targeted coring of the lake deposits provides ground-truthing of the disturbed deposits. Analysis of organic or sediment materials sampled from recovered cores allow ages to be assigned to the event layers. Maps depicting the distribution, extent and types of disturbed deposits within each event layer can be compiled by integrating the event layer stratigraphy and the three-dimensional architecture of the lake deposits. An intrabasin, multi-deposit event layer is the likely signature of significant past earthquake shaking, but possible non-seismic triggers also need to be assessed. An earthquake catalogue spanning 16000 years for central Switzerland exemplifies the results of an integrated seismo- and chrono-stratigraphic approach to paleoseismic investigation. This approach to the investigation of eastern Canadian lake basin(s) has the potential to significantly augment the eastern Canadian earthquake catalogue. Conversely, the absence of seismically-induced disturbed deposits in SAP profiles and in lake core within a given area can help establish negative evidence of paleoseismicity.

\section{RÉSUMÉ}

Les secousses sismiques peuvent provoquer des mouvements de terrain, des turbidites, ainsi que la déformation de sédiments meubles dans les bassins lacustres. Ces dépôts "perturbés » lorsque préservés constituent des archives stratigraphiques de ces paléoséismes. Une sismostratigraphie tridimensionnelle des dépôts lacustres peut être élaborée par sondage acoustique haute densité de sédiment (SAP), permettant ainsi de détecter et de cartographier les dépôts perturbés du bassin. Les couches événementielles composées d'un dépôt perturbé ou plus peuvent être détectées par sismostratigraphie, et le carottage ciblé de dépôts lacustres permet de les valider. L'analyse de matériaux organiques ou de sédiments prélevés à partir des carottes permettent de dater les couches événementielles. Des cartes illustrant la distribution, l'étendue et les types de dépôts perturbés au sein de chaque couche événementielle peuvent être compilées en intégrant la stratigraphie de la couche événementielle et l'architecture tridimensionnelle des dépôts lacustres. Une couche événementielle multi-dépôt est la signature probable d'importants tremblements sismiques anciens, sans perdre de vue que d'autres déclencheurs non sismiques puissent être en cause. Un catalogue de séismes couvrant 16000 ans d'événements dans le centre de la Suisse illustre les résultats d'une approche sismologique et chrono-stratigraphique intégrée de l'histoire paléosismique. Cette approche d'étude de bassins lacustres de l'Est canadien permet d'augmenter considérablement le nombre de séismes du catalogue de l'Est canadien. Inversement, l'absence de dépôts perturbés induits par séisme dans les profils SAP et dans des carottages d'une zone donnée peut contribuer à constituer une preuve de l'absence de paléosismicité.

Traduit par le traducteur

\section{INTRODUCTION}

Paleoseismology is a relatively young sub-field of earthquake geology that studies the location, timing and magnitude of prehistoric earthquakes (McCalpin and Nelson 2009; Audemard and Michetti 2011). The results of a paleoseismic study contribute to a better understanding of the probability and severity of future, strong earthquakes that happen infrequently and may not have occurred within recorded history. Paleo- 
seismic results supplement instrumental and historical records, which for Canada are relatively short, spanning up to only about 400 years in a few places (Lamontagne et al. 2008). Paleoseismic studies increase the fundamental understanding of earthquake occurrence, and help improve the seismic standards for both building design and the design, operation and regulation of critical infrastructure.

Lake basins contain a continuous to near-continuous archive of long-term sedimentation that has a high potential for preservation. It was recognized in the early-to-mid 1970s that soft-sediment deformation in lacustrine deposits can be the product of seismic shaking and thus can record earthquakes (Sims 1973, 1975). Subsequently, sub-bottom profile surveys in some lake basins identified the presence of widespread subaqueous mass movement (slump) and turbidite deposits that were attributed to moderately strong historical earthquakes (e.g. Shilts 1984; Siegenthaler et al. 1987; Shilts and Clague 1992). The connection between seismicity and the occurrence of mass movement, turbidite, and soft-sediment deformation deposits (collectively referred to in this paper as 'disturbed deposits') has been developed more fully by comparing stratigraphic records of disturbed lake deposits to longer records of historical seismicity (e.g. Siegenthaler et al. 1987; Doig 1990, 1991; Chapron et al. 1999; Monecke et al. 2004; Nomade et al. 2005). The paleoseismic record preserved in lake basin deposits has been investigated by numerous researchers globally (e.g. Beck et al. 1996; Karlin and Abella 1996; Schnellmann et al. 2002, 2006; Karlin et al. 2004; Carillo et al. 2006; Monecke et al. 2006; Strasser et al. 2006, 2013; Moernaut et al. 2007; Upton and Osterberg 2007; Bertrand et al. 2008; Anselmetti et al. 2009; Beck 2009, 2011; Maloney et al. 2013; Morey et al. 2013).

This paper presents an integrated seismo- and chronostratigraphic methodology for investigating (paleo)earthquake signatures preserved in freshwater lake deposits; this methodology is particularly applicable to the intracratonic setting of eastern Canada, where there are numerous lakes in areas of southern Quebec and southeastern Ontario that have experienced significant historical seismicity. The focus is on secondary, off-fault evidence of paleoseismicity (McCalpin and Nelson 2009) in the form of multiple occurrences of disturbed deposits, and on demonstrating their synchronous formation within a basin or (ideally) between basins. Emphasis on secondary disturbed deposits rather than primary paleoseismic evidence is consistent with the fact that there has been only one surface rupture associated with a historic earthquake in eastern Canada (the 1989 Ungava earthquake of $\mathrm{M}_{\mathrm{S}}$ 6.3; Adams et al. 1991). In other documented historical eastern Canadian earthquakes, including the AD 1663 Charlevoix earthquake (estimated $\mathrm{M}_{\mathrm{w}} 7.2 \pm 0.2$; Locat 2011), the fault plane was blind or subaqueous, or the surface expression of the ground rupture was not sufficiently strong to have (yet) been recognized. In contrast, well-developed occurrences of seismically-induced disturbed deposits that are attributed to historic earthquakes have been reported for a number of eastern Canadian lake basins, as presented below.

\section{SUB-BOTTOM ACOUSTIC PROFILING SURVEYS}

Sub-bottom acoustic profiling (SAP) is an integral part of many investigations of lake-bottom sediments (see Scholz
2001), and has geological, environmental and limnological applications. SAP surveys provide insights into the composition and sedimentary architecture of sub-bottom sediments, and have been used for several decades to investigate disturbed lake-bottom sediments associated with seismic shaking. The initial studies using SAP were conducted in lake basins proximal to the epicenter of strong historic earthquakes (Shilts 1984; Clague et al. 1989). They revealed the presence of subaqueous mass movement deposits and turbidite deposits that were attributed to the rapid failure of basin-margin sediments triggered by the historic earthquake. Generalized characteristics of subaqueous mass movement deposits and the associated turbidite deposits in SAP returns are summarized in Table 1 , and an example of an SAP profile containing disturbed deposits is shown in Figure 1. In some studies, recognition of subaqueous failures explained lake phenomena observed at the time of the historic earthquake, such as the occurrence of tsunami or seiche oscillation waves (e.g. Siengenthaler et al. 1987; Chapron et al. 1999) or changes in lake turbidity (e.g. Shilts 1984; Shilts and Clague 1992).

Recent paleoseismic studies have applied SAP surveys using a high-density line spacing (Fig. 2) that allows a pseudothree-dimensional seismo-stratigraphy of the lake deposits to be constructed (e.g. Schnellmann et al. 2002, 2006; Monecke et al. 2006; Strasser et al. 2006, 2013; Moernaut et al. 2009). From this, the spatial and stratigraphic locations of disturbed deposits within the basin can be identified and mapped to define 'event layers', as summarized below. SAP surveys are also important for locating coring sites that target disturbed deposits of interest.

A high-resolution bathymetry map or digital elevation model obtained from a multibeam survey can be a useful supplement to SAP data. Such maps have been used to delineate mass movement features in which the source and depositional areas have an obvious topographic surface expression on the lake bottom (Micallef 2011). Using multibeam bathymetry, small-scale mass movement features have been identified that might not be recognized from a SAP survey (Normandeau et al. 2013). Most of the paleoseismic lake studies cited in this paper, however, do not include multibeam bathymetric data.

\section{CORING}

Coring is a fundamental part of lake deposit investigations and provides ground-truthing of the SAP returns. There are many examples of paleoseismic studies that combine SAP surveys and collection of core (e.g. Inouchi et al. 1996; Shiki et al. 2000; Monecke et al. 2004; Schnellmann et al. 2006; Moernaut et al. 2007; Beck 2009, 2011; Anselmetti et al. 2009; Strasser et al. 2013). Core logging (e.g. multi-spectral sensor, x-ray and/or lithological description of split core), sub-sampled sediments and macrofossils provide data for interpreting the stratigraphy, depositional environment, and chronology of the recovered deposits.

Recovered core provides a sample of the sediment column at a specific point location within a lake basin. In isolation, interpretation of core deposits can be hampered by the narrowness of the core, but the two- and pseudo-three-dimensional context of the sub-bottom architecture and stratigraphy provided by SAP returns can aid core interpretation substantially. This spatial context can also support the correlation of 
Table 1. Characteristics of mass movement and turbidite deposits in sub-bottom acoustic profile (SAP) returns in lake basins.

\begin{tabular}{ll}
\hline \hline $\begin{array}{l}\text { Geomorphic } \\
\text { feature }\end{array}$ & Description \\
\hline Subaqueous & - product of downslope sliding, rotation, or flow of \\
mass & sediment under the force of gravity \\
movement & - failed mass can involve the slipping, sliding and \\
deposits (or & rotation of coherent material, movement of highly \\
slump, mass- & broken debris, or a combination of both. \\
transport, & - materials originate from steep to low angled slopes on \\
mass-flow & basin side(s). \\
and mudflow & - scale of failure can vary widely, reflecting in part the \\
deposits) & thickness and character of the source area deposits.
\end{tabular}

\section{Deposit characteristics}

- form sedimentary bodies from few tens to hundreds of metres in lateral extent that may occur individually or within coalescing masses. Source of failure may be on overlying slope.

- internally lacks continuous reflectors and appears transparent, chaotic, or chaotic-to-transparent in SAP returns. 'Blocks' of disoriented internal reflectors may be present.

- in profile, deposits commonly are wedged-shaped, thin basin-ward, and commonly pinch out laterally. exhibits a hummocky to relatively smooth upper surface. dragging or loading during emplacement may cause disruption-deformation-folding-faulting of underlying and adjacent lacustrine deposits.

- lower boundary between mass movement and lacustrine deposits may be indistinguishable in returns.

characterized by a smooth surface and a geometry that appears to be 'ponded' in deeper portions of basin. may be laterally extensive and up to several metres thick; thin deposits can fall below resolution of SAP returns. may overly mass movement deposits.

internally is transparent in SAP returns.

some thick deposits consist of a near-uniform (i.e., homogenous), mass of fine-grained clay-silt overlying a thick, coarser-grained (silty to sandy) deposit, and are called a 'homogenite' or 'megaturbidite' deposit.

Sources $\quad$ Prior et al. (1984); Siegenthaler et al. (1987); Shilts and Clague (1992); Shilts et al. (1992); Chapron et al. (1999); Monecke et al. (2006); Schnellmann et al. (2006); Strasser et al. (2013)
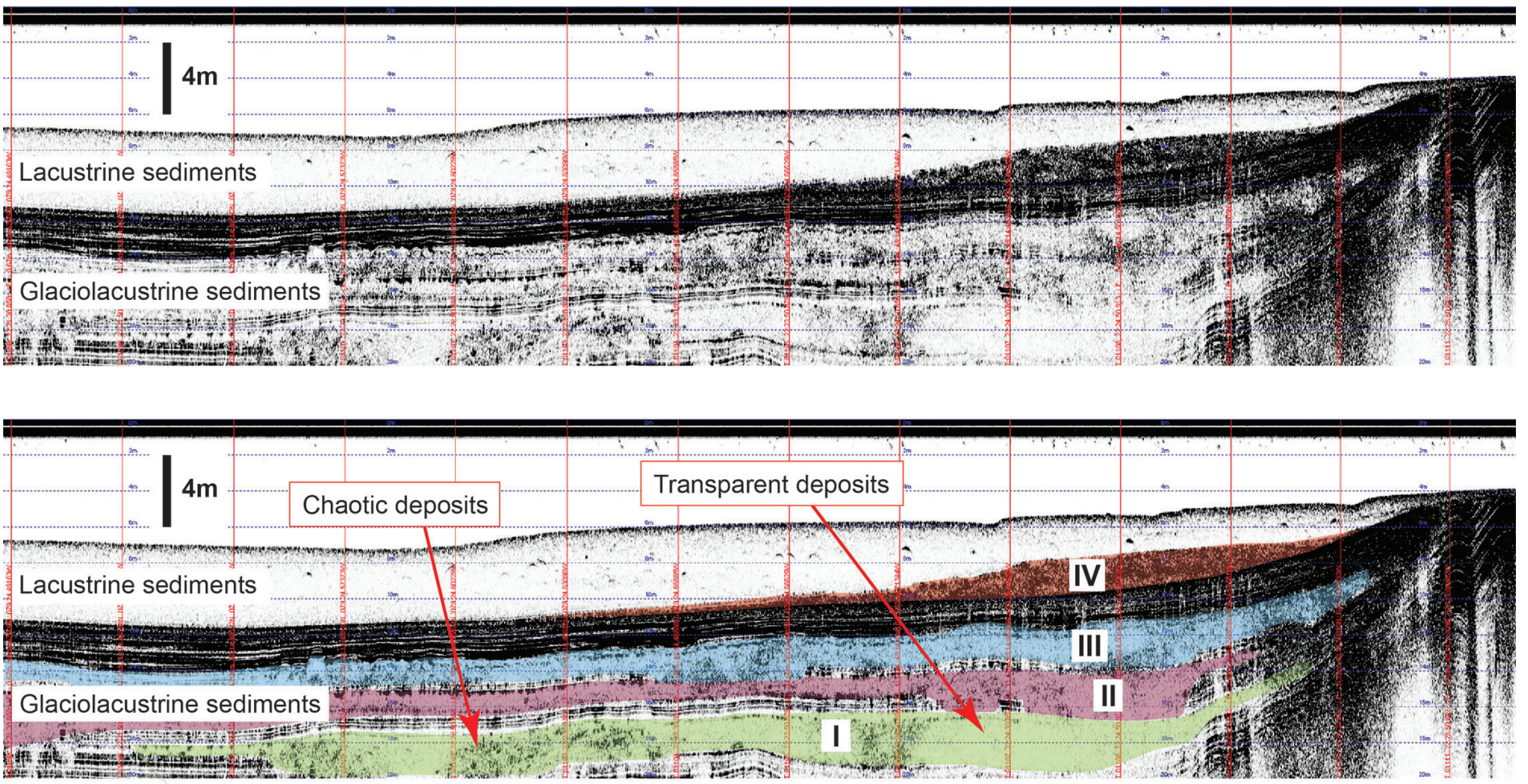

Figure 1. Uninterpreted (upper) and interpreted (lower) versions of the same SAP returns, showing four sets of disturbed deposits within sub-bottom sediments of Lac Dasserat, near Rouyn-Noranda, Quebec (see Fig. 6b for location). The deposits labeled I, II and III occur within glaciolacustrine deposits and those labeled IV occur at the interface between glaciolacustrine and overlying lacustrine deposits. Note the chaotic and transparent character of the returns within the disturbed deposits. The mechanism that produced the disturbed deposits has not been investigated, but paleoearthquakes are a possibility. 


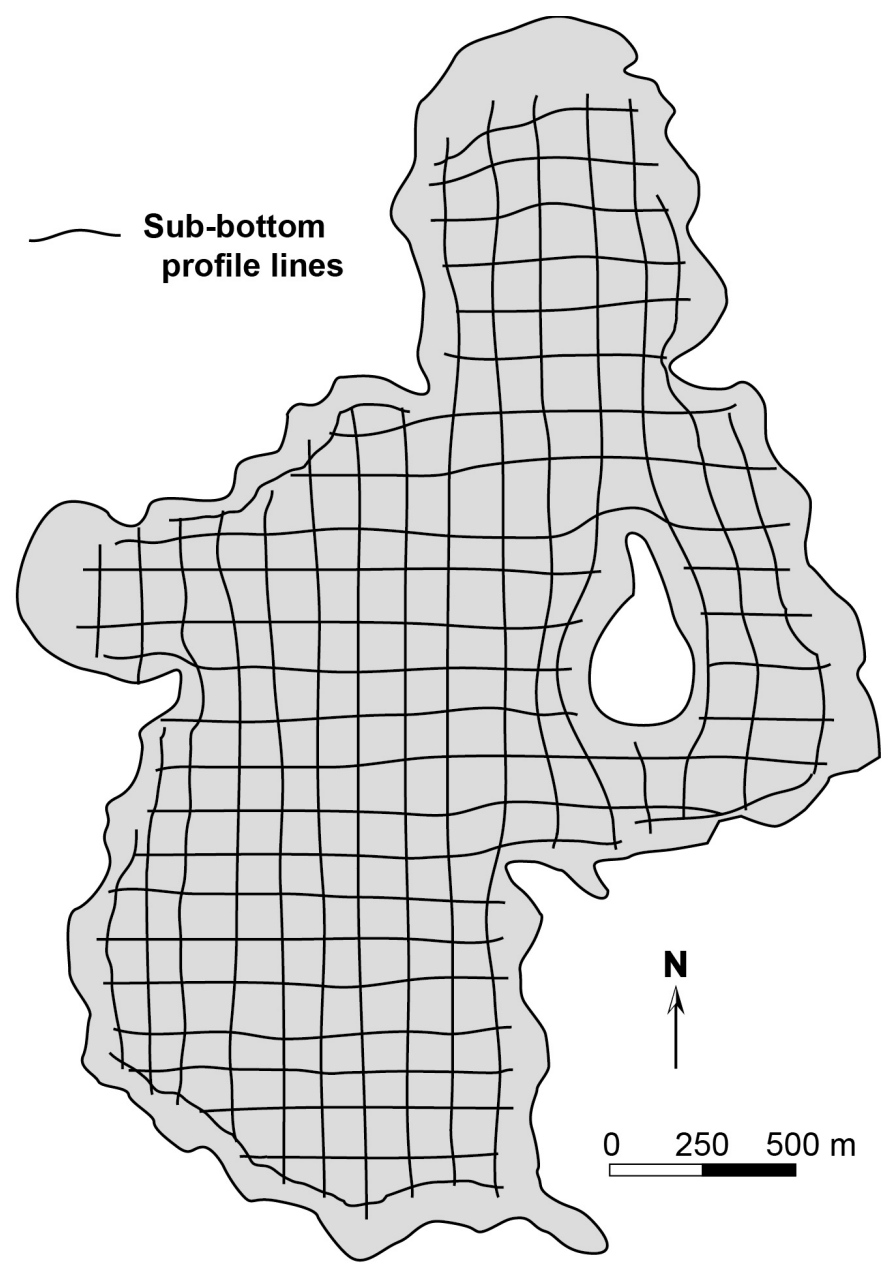

Figure 2. Schematic diagram of a high-density sampling pattern for a sub-bottom profile survey. Spacing density of the grid might be increased locally to focus on sub-bottom features of interest.

specific layers between coring sites that might otherwise be conjectural in cases when the physical properties of the deposits exhibit significant lateral variation or the coring sites are widely spaced. Thus, SAP surveys and the collection of core are complementary and mutually supportive.

A coring program should be designed after collection and interpretation of SAP survey data to target specific sub-bottom disturbed deposits and other deposits of interest. The integration of SAP and core data is maximized when core sites lie along SAP survey lines. Coring sites can also be chosen to minimize water depths and maximize the depth of penetration into the sub-bottom for a given length of core barrel, which affects the choice of core collection techniques. Glew et al. (2001) and Leroy and Coleman (2001) provide comprehensive reviews of, respectively, short $(<10 \mathrm{~m})$ and long $(>10 \mathrm{~m})$ coring methods for recovering lacustrine sediments.

Because coring yields a physical sample of lake bottom deposits, the sedimentological properties can be recorded in more detailed than can be inferred from only an SAP survey. Furthermore, a number of paleoseismic studies have demonstrated that disturbed deposits can form thin layers that are below the resolution of SAP returns (less than $0.2-0.5 \mathrm{~m}$ ). These thin layers can be silt deposits within gyttja (Doig 1986, 1990), homogenite layers (a sub-type of turbidite layer; Chapron et al. 1999; Schnellmann et al. 2006), or soft-sediment deformation features (e.g. microfault, loading, and liquefaction structures; Monecke et al. 2004, 2006). Recognizing the occurrence of thin disturbed deposits in a basin is important in a paleoseismic investigation because such features may be evidence of less intense shaking. This is particularly relevant for interpreting whether an event layer has a non-seismic or seismic origin, which is based in part on the characteristics (number, scale, and distribution) of the disturbed deposits (Monecke et al. 2006; Strasser et al. 2013).

\section{SUBAERIAL GLACIOLACUSTRINE DEPOSITS}

Large areas of eastern Canada were inundated temporarily by glacial lakes or marine waters at the end of the late Pleistocene and during the early Holocene (Dyke et al. 2003). Their deposits persist in the subaerial landscape and can be exposed along river courses, lake bluffs, roads, railway cuts, and excavation sites. These exposures may be tens of metres or more long, and thus provide far greater detail of disturbed deposits than recovered core and SAP returns of lake deposits. Subaerial exposures, however, potentially contain only the older portion of the sediment column contained within a nearby lake basin(s) because aggradation was interrupted by the recession of the water body. Nevertheless, where present, such exposures can provide a useful supplement to SAP survey and core data. Examples of the use of subaerial glaciolacustrine and lacustrine deposits in paleoseismic studies are Adams (1982, 1989, 1996), Bowman et al. (2004), Carrillo et al. (2006) and Hermanns and Niedermann (2011). In Sweden, occurrences of turbidite, disturbed, deformed, and tsunami deposits within subaerial glaciolacustrine and glaciomarine deposits contributed to the development of an earthquake catalogue that spans 12000 years (Mörner 2003, 2005, 2009).

\section{CHRONOLOGY}

Absolute age dating is critical to the development of a chronostratigraphy of lake deposits imaged in SAP returns and recovered in cores. Chrono-stratigraphy itself is important for correlating disturbed deposits throughout a given lake basin and for determining the age of event layers. Chrono-stratigraphy is also essential for correlating potential seismically-induced event layers to known historical earthquakes, between lake basins, and to other paleoseismic evidence in the area (e.g. a fault scarp, liquefaction features, or subaerial landslides). For a basin containing multiple event layers that have been interpreted to record paleoearthquakes, estimations of the time between earthquakes and the average return period are derived from the chrono-stratigraphy.

A maximum age for a sequence of glaciolacustrine deposits is provided by the time of deglaciation, which is known approximately in most areas of Canada (Dyke et al. 2003). In areas inundated by large, late-glacial lakes, an approximate age can also be obtained for the glaciolacustrine - lacustrine boundary, which usually is well defined in SAP returns (Shilts 1984; Shilts and Clague 1992), if the time of glacial lake recession is known.

To obtain a detailed chronology, however, collected core must span as much of the glaciolacustrine - lacustrine sequence as possible. There are numerous dating methods that can be applied (or potentially applied) to determine the age of deposits in eastern Canada; selected examples are summarized 
in Table 2. All of these methods involve the analysis of sediment or organic materials contained in recovered core. A condensed or composite core for a basin can be constructed by correlating stratigraphical and sedimentological features between cores with the aid of the SAP returns and chronological data.

All dating methods provide ages at specific depths or intervals over the length of core. Ideally, the dated materials will be spaced regularly along the core length so that there are no large gaps in depth/age (see Fig. 3). Ages can be estimated for depth ranges that lack chronology by extrapolating a linear age-depth function between data points, although sediment compaction and the presence of thick, rapidly-accumulated beds in the stratigraphy need to be considered (Doig 1998a; Monecke et al. 2006). Age estimates become highly questionable when extrapolations are made well beyond the range of the age-depth data; for example, a $20^{\text {th }}$ century age-depth function extrapolated over many centuries, or a mid-Holocene function extrapolated thousands of years into the early Holocene or late Pleistocene.

Detailed chrono-stratigraphies of lake deposits in intracratonic settings have been developed in support of a number of paleoseismic studies. The time scales differ substantially, from several hundred to 17000 years. Notable studies with welldeveloped chronologies are Schnellmann et al. (2002, 2006), Monecke et al. (2004, 2006), Becker et al. (2005), Strasser et al. (2006, 2013) and Beck (2011). Long, detailed chrono-stratigraphies have been developed by Canadian paleoseismic studies in marine inlet or fjord settings (e.g. Blais-Stevens and Clague 2001; St.-Onge et al. 2004; Blais-Stevens et al. 2011; Enkin et al. 2013), but no comparable results have been reported for a paleoseismic investigation of an eastern Canadian lake basin.

\section{EVENT LAYERS}

An 'event layer' is a bed or level within a lake basin stratigraphic column that includes one or more disturbed deposits (mass movement, turbidite or soft-sediment deformation deposit(s); Fig. 4; see Schnellmann et al. 2002, 2006; Strasser et al. 2013). Spatially separate disturbed deposits are included in the same event layer if they occur at the same stratigraphic level (Fig. 4), which implies that they formed synchronously. An event layer age can be interpreted from the chrono-stratigraphy of the lake deposits.

By integrating event layer stratigraphy and the three-dimensional architecture of the lake deposits obtained from a SAP survey, a map can be produced showing the extent and types of disturbed deposits within each event layer (see Fig. 5). A series of maps, each representing separate event layers, depict the reconstructed history of failures, sediment remobilization and transport processes, and/or in situ deposit disturbances within a lake basin (Fig. 5; Strasser et al. 2013). These maps allow the number, types, locations and scale of disturbed deposits forming the event layers to be compared. A multideposit event layer consisting of, for example, multiple mass movements and a major turbidite deposit can be readily distinguished from one containing an isolated, small-scale, mass movement deposit (compare events $\mathrm{E}$ and $\mathrm{F}$ in Fig. 5). The establishment of event layer ages allows the event stratigraphy reconstructed in nearby lake basins to be compared, which is important for corroborating a seismic interpretation and identifying the signature of stronger paleoearthquakes.

\section{INTERPRETING A PALEOEARTHQUAKE SIGNATURE}

Many studies document that subaqueous mass movement and turbidite deposits in lake basins have been triggered by historic earthquakes. However, such deposits are not exclusively the product of seismic shaking, and can be triggered by non-seismic mechanisms such as the collapse of a delta front, groundwater sapping, a subaerial landslide that flows into a lake and triggers a subaqueous failure, and human activities along shorelines (Shilts and Clague 1992). Any interpretation of a trigger, therefore, must consider all reasonable mechanisms as well as the context of the disturbed deposits within the basin and the broader area surrounding the basin (Jibson 2009; Owen et al. 2011). It is not always possible to conclusively establish the triggering mechanism for the failures; therefore, an interpreted mechanism, whether seismic or non-seismic, commonly represents the best explanation rather than a definitive one (Lucchi 1995). Nevertheless, studies of lake basins (e.g. Siegenthaler et al. 1987; Chapron et al. 1999) as well as offshore and inlet settings (e.g. Adams 1990; Syvitski and Schafer 1996) demonstrate that the occurrence of multiple, synchronous mass movements is a likely signature of significant past earthquake shaking. The correlation of independent mass movement deposits within a lake basin therefore constitutes key evidence supporting a paleoearthquake hypothesis (Wheeler 2002); correlating multi-deposit event layers between nearby lake basins provides strong corroboration for the interpretation of a seismic trigger (Monecke et al. 2006; Strasser et al. 2013).

\section{SELECTED CASE STUDIES FROM SWITZERLAND}

Schnellmann et al. $(2002,2006)$ used three-dimensional seismo-stratigraphy and chrono-stratigraphy to identify past episodes of multiple, synchronous mass movements preserved in lacustrine and glaciolacustrine deposits of Lake Lucerne, central Switzerland (Fig. 6a). Nineteen event layers consisting of one to nineteen separate occurrences of disturbed deposits were recognized in the lake deposits (Schnellmann et al. 2006). Seventy-five of ninety-one separate mass-flow deposits occurred within six multi-deposit event layers. The youngest event layer comprised 13 separate mass-flow deposits overlain by two thick turbidite deposits and was correlated to a historic AD 1601 earthquake of $M_{\mathrm{w}} 5.9$ (recently revised from $\mathrm{M}_{\mathrm{w}}$ 6.2; see Strasser et al. (2013) and references therein) that damaged structures in Lucerne. Schnellmann et al. (2006) interpreted the five older multi-deposit event layers to have been triggered by strong paleoearthquakes comparable to the $\mathrm{AD}$ 1601 earthquake, based on similar multi-deposit signatures. Possible non-earthquake triggers were assessed, but considered to be unlikely for the reasons summarized in Table 3 .

Monecke et al. (2004) identified four event layers in cores recovered from lakes Baldegger, Lungerer, Sarner and Seelisberg in an area surrounding Lake Lucerne (Fig. 6a). They attributed these layers to four historic earthquakes, the oldest occurring in AD 1356. The types of disturbed deposits observed in the lakes, as well as those reported from Lake Lucerne, were evaluated against published patterns of local ground shaking intensities estimated for the historic earthquakes. By comparing the disturbed features to the local historic intensities and considering the differences in both between lake basins, Monecke et al. (2004) concluded that the 


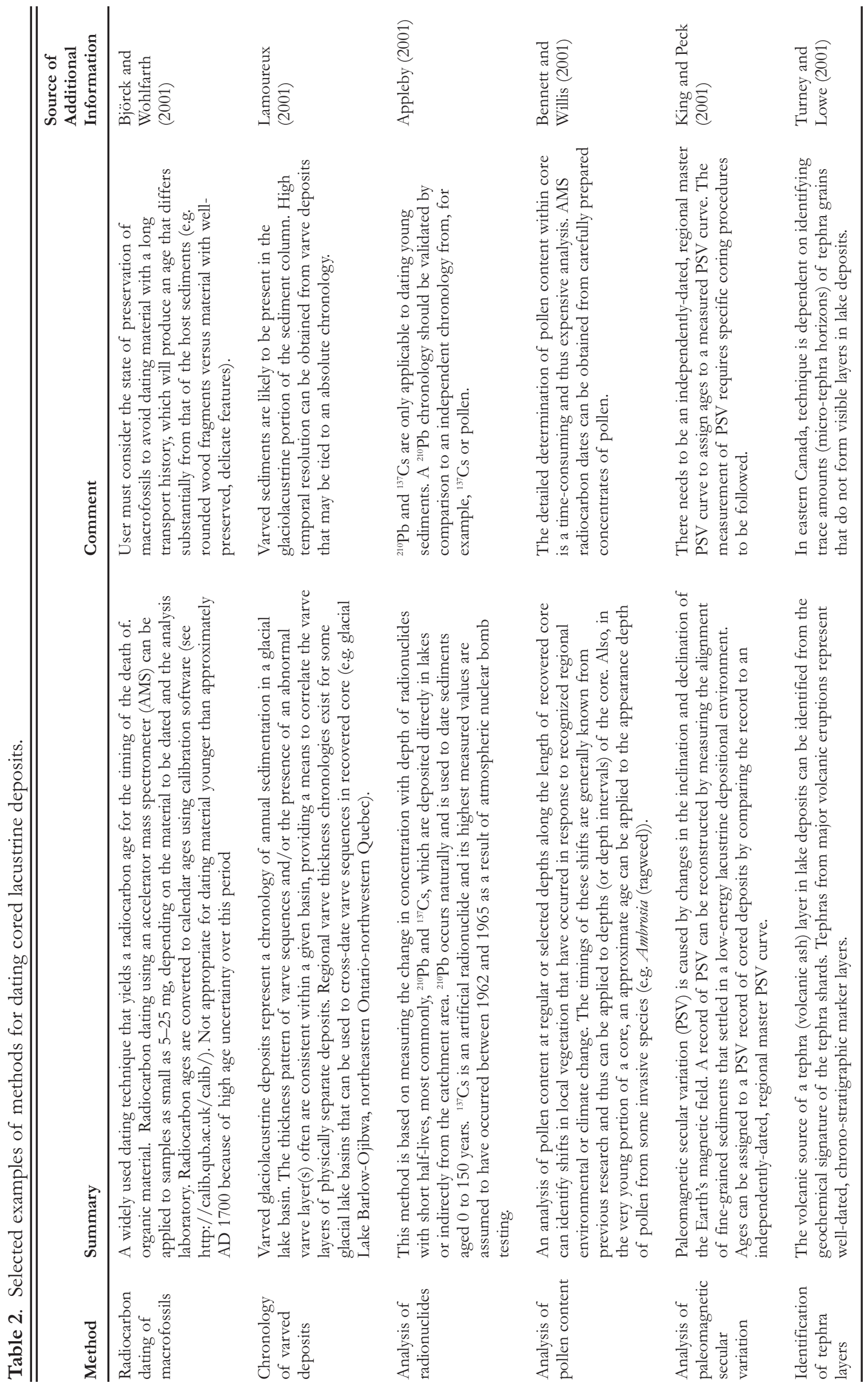




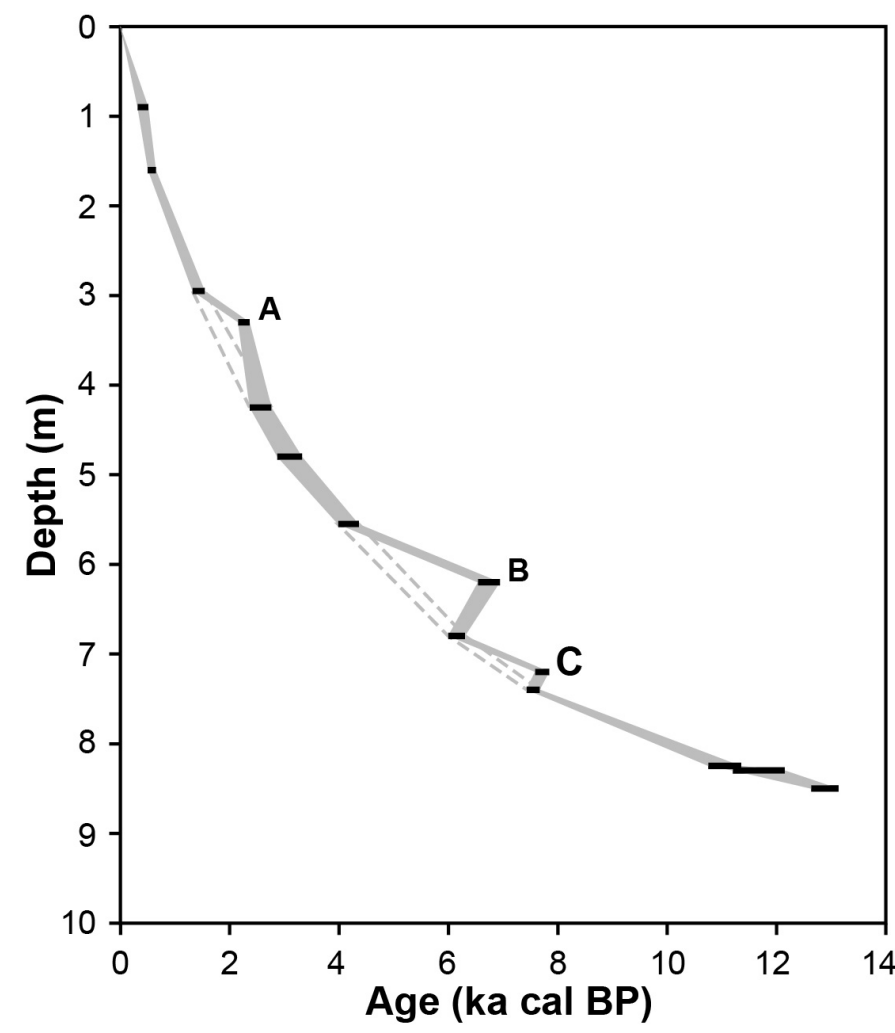

Figure 3. Plot of 14 calibrated radiocarbon ages versus depth from a composite core from Lake Seelisberg, Switzerland (see Fig. 6a for location; data from Monecke et al. 2006). Each age is represented by a black bar scaled to the two standard deviation error range of the calibrated radiocarbon age. The 14 ages are distributed regularly through the $\sim 9 \mathrm{~m}$-long core and $\sim 13000$ year time span. The general slope of the plot is curvilinear and it decreases with depth. There is concordance in the age-depth position of most data points, except for A, B and C. ka cal BP = thousands of years (calibrated) before present. threshold for disturbance formation was between intensities VI and VII (European Macroseismic Scale, or EMS). Above the threshold, small-scale structures begin to form, such as disturbed/contorted laminations and liquefaction structures, whereas large-scale mass movements begin occurring between intensities VII and VIII (EMS). The threshold magnitude for deformation was estimated to be $\mathrm{M}_{\mathrm{w}} 5.3$ (recently revised from $M_{W}$ 5.7; see Strasser et al. (2013) and references therein), which falls within the threshold range of $\mathrm{M}_{\mathrm{w}} 5.0-5.5$ for the formation of liquefaction structures, as reported by Obermeirer (1996, 2009).

Monecke et al. (2006) combined the historic and prehistoric earthquake records for three of the lakes (Baldegger, Lungerer, and Seelisberg) investigated by Monecke et al. (2004), along with the earthquake record from Lake Lucerne reported by Schnellmann et al. (2006), to produce an integrated earthquake catalogue for central Switzerland. Strasser et al. (2013) enhanced this catalogue by adding the earthquake record interpreted from the event layers preserved in Lake Zurich, also located in central Switzerland (Fig. 6a). As shown in Figure 7, the resulting enhanced earthquake catalogue spans 16000 years and shows all of the identified event layers for each lake basin. Characteristics of the event layers are depicted symbolically (e.g. single versus multi-deposit, mass movement - turbidite versus in situ disturbed deposits). Event layers, which are interpreted to be seismically triggered and have common ages, are correlated between basins in Figure 7 . The degree of confidence in the seismic-trigger interpretation is represented by a high-medium-low probability level, based on the supporting evidence. A high probability designation was applied where event layers could be correlated with historic earthquakes, or were correlated between two or more basins and the evidence in at least one of the basins includes a relatively large number of failures (e.g. event $\mathrm{F}$ in Figure 5). A

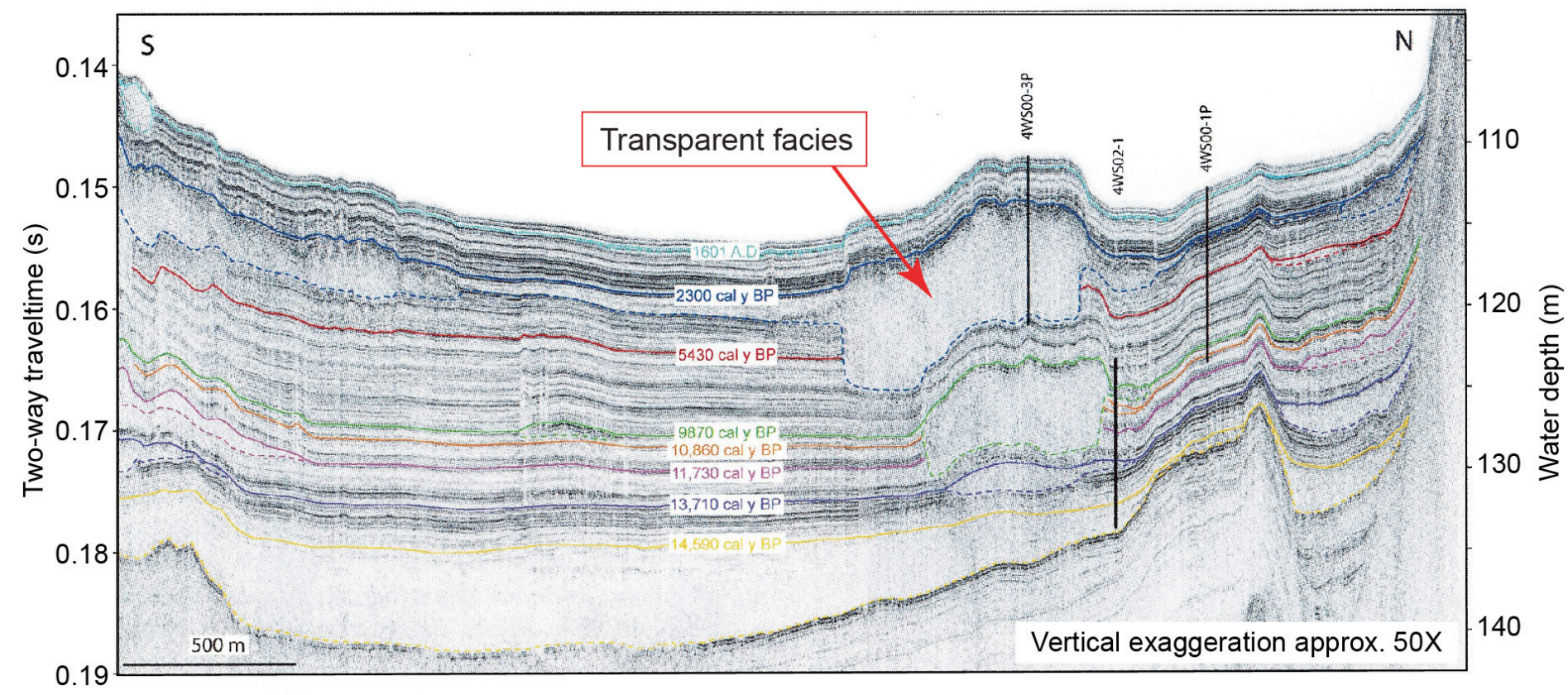

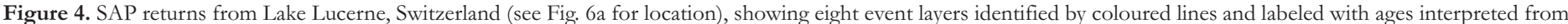

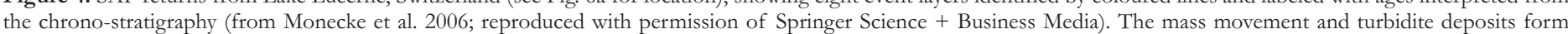

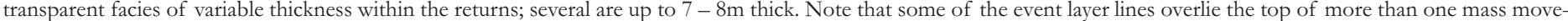
ment or turbidite deposits, indicating synchronous deposition within the event layer (e.g. the $2300 \mathrm{cal}$ yr BP line). 

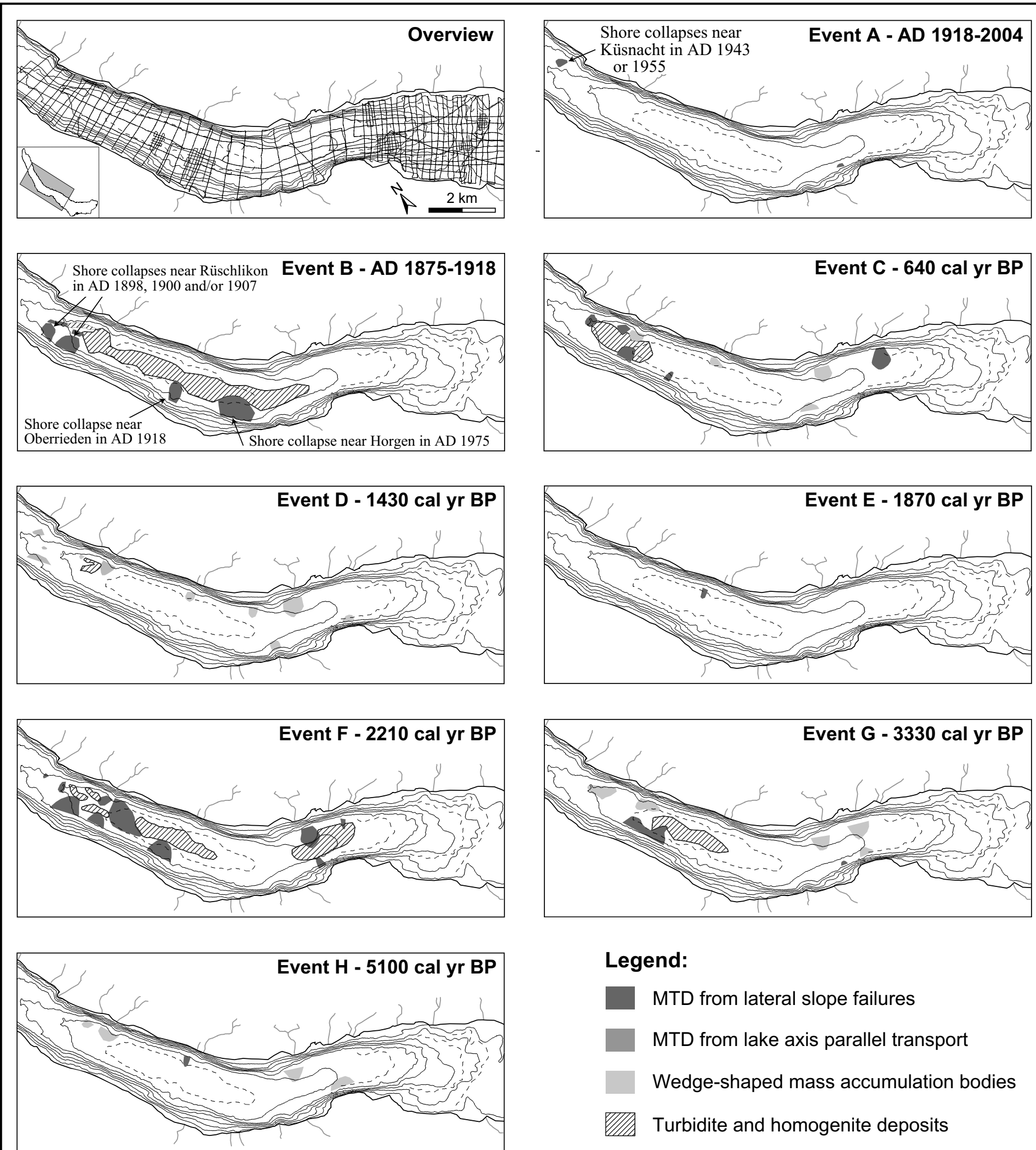

Figure 5. Maps of dated event layers in the sub-bottom of Lake Zurich, Switzerland (see Fig. 6a), as defined from high-density seismo- and chrono-stratigraphic data (modified from Strasser et al. 2013; reproduced with permission of John Wiley \& Sons, Inc.). Events B, C, F and G consist of multiple 'mass-transport deposits' (MTD) and contrast markedly with events $\mathrm{A}, \mathrm{D}, \mathrm{E}$ and $\mathrm{H}$, which are composed of much smaller, single MTD deposits. The density of the sampling pattern for collection of sub-bottom acoustic profile data is shown on the overview map at the upper left. Note that event B is composed of several historic, separate, anthropogenically-triggered, shoreline collapses. 


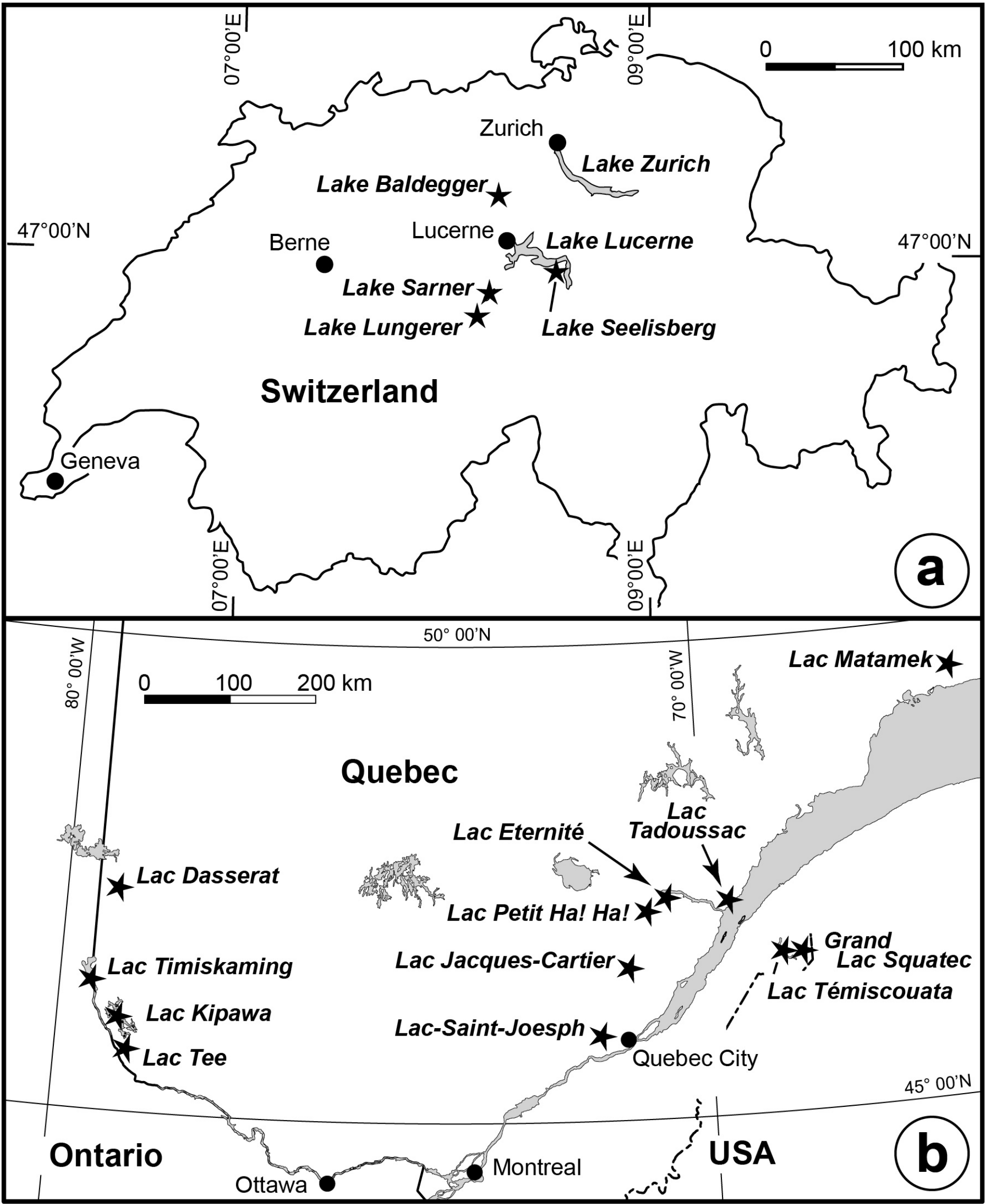

Figure 6. Maps of a) Switzerland and b) eastern Canada showing the locations of the lakes mentioned in the text. 
Table 3. Alternative non-seismic mechanisms considered and rejected for the creation of multi-deposit event layers in Lake Lucerne (after Schnellmann et al. 2006).

\begin{tabular}{ll}
\hline \hline Possible non-seismic mechanism & Rationale for rejection \\
\hline Overloading or oversteepening of subaqueous slopes. & $\begin{array}{l}\text { Considered unlikely to generate multiple, synchronous failures } \\
\text { because the failed slopes have different orientations and occur at } \\
\text { different depths. }\end{array}$
\end{tabular}

Flood events triggering subaerial landslides, submarine debris flows, and turbidity currents (hyperpycnal flows).

Wind-generated waves.

Displacement wave (tsunami) generated by subaerial landslide.
May trigger multiple failures, but doesn't explain the occurrence of submarine failures on deeply submerged slopes or on slopes situated far from shoreline.

Considered unlikely because limited fetches restrict the size of waves that can be reasonably generated. Failed slopes in deeper water would be unaffected by wave movements.

Wave may trigger submarine failures in basin. Only considered a possible factor for a single mass movement deposit within one of the multi-event layers that is located opposite subaerial landslide. Other failures within this event layer are located elsewhere in basin, including one with a source area situated at $70 \mathrm{~m}$ depth, thus were considered unlikely to have been triggered by displacement wave.

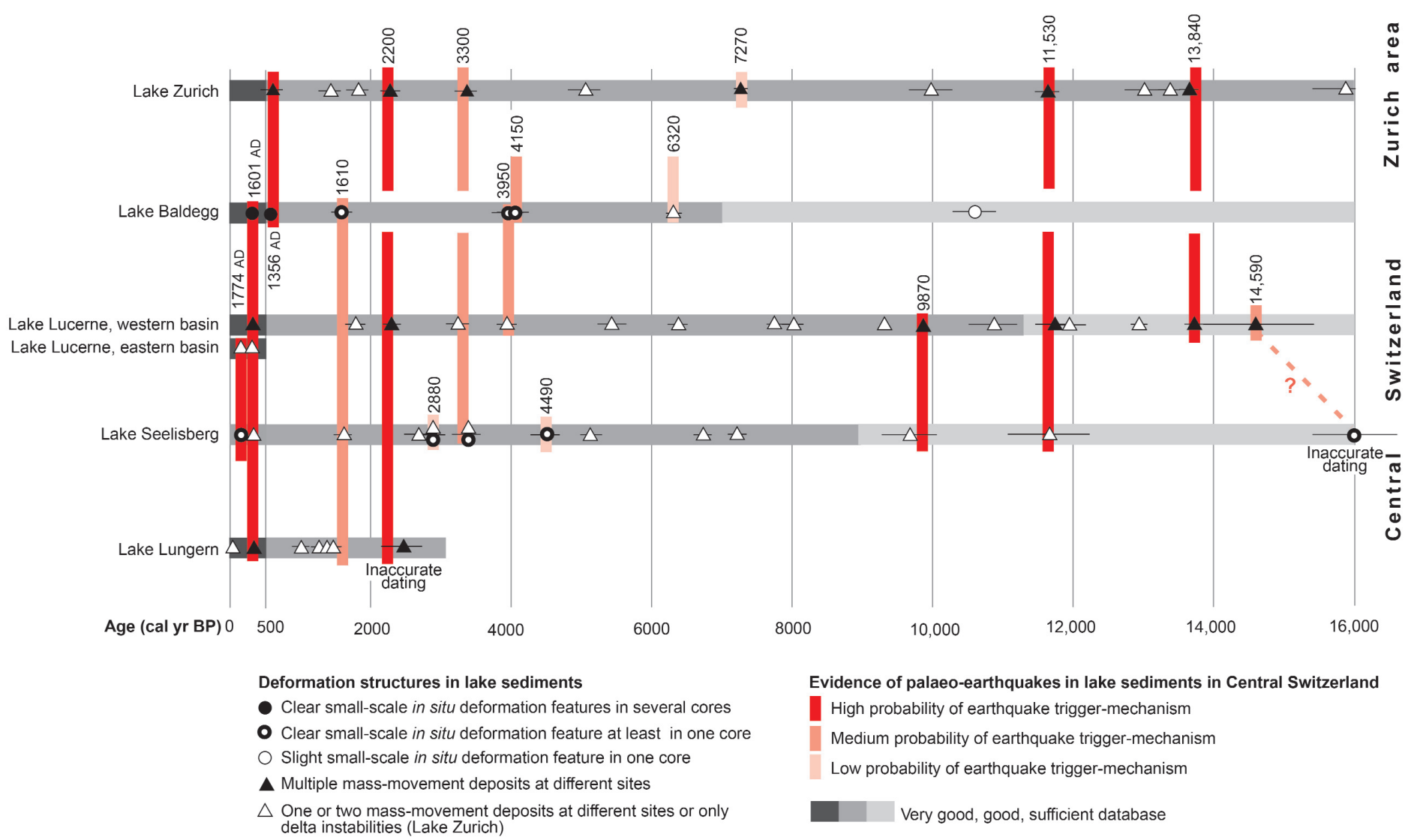

Figure 7. Catalogue of central Switzerland earthquakes spanning the past 16000 years. The catalogue is based on historical records and paleoseismic investigation of five lake basins (modified from Strasser et al. 2013; reproduced with permission of John Wiley \& Sons, Inc.). See text for explanation.

medium probability designation was assigned if seismicallyinduced deformation is evident in one basin and further deformation was present in another. Small-scale soft-sediment deformation was considered to be seismically induced if it occurred without evidence of sediment overloading or deformation by an overlying or adjacent mass movement deposit, and when the deformed deposits could be correlated between two or more cores. A low probability was assigned in cases where possible seismically-induced deformation was present in only one basin (e.g. several small failures or soft-sediment deformation in a single core). Event layers composed of single-deposit evidence (e.g. a single failure) that occurred in only one basin are also shown on Figure 7, but they were not interpreted to represent paleoearthquakes. 
Table 4. Possible reasons for an incomplete catalogue of earthquakes from a given lake basin (modified from Schnellmann et al. 2006).

- Limited penetration of acoustic energy into lake sub-bottom.

- Reworking and/or deformation by younger larger failures may have caused small and/or older mass movement deposits to be unrecognized.

- A thin deposit with limited extent is unrecognized in SAP returns and is missed in collected core.

- Indistinct reflector forming the top or pinch-out point of a deposit.

- Signature of the second of two closely-occurring earthquakes is subdued because insufficient time has passed to recreate conditions on basin slopes for multiple failures.

The earthquake catalogue for central Switzerland includes seven paleoearthquakes identified by the occurrence of multiple mass movement deposits or soft-sediment deformation features in at least two lake basins. Notably, paleoearthquakes about 13 800, 11530 and 2200 years ago were considered to be strong, based on the high number of mass movement deposits forming the respective multi-deposit event layers in lakes Zurich and Lucerne, which are located $\sim 40 \mathrm{~km}$ apart (Strasser et al. 2013). Strasser et al. (2013) developed seismotectonic scenarios for these three paleoearthquakes, based on the spatial pattern of the minimum magnitude required to produce the observed multiple failures in the lake basins.

Although the earthquake catalogue is the product of detailed investigations, Schnellmann et al. (2006) recognized that there may be events missing from the individual lake records, for reasons listed in Table 4. Nevertheless, the earthquake catalogue for central Switzerland exemplifies what can be produced from detailed and integrated seismo- and chronostratigraphical investigations of lake deposits from a single basin, and especially multiple, relatively close basins. This catalogue, however, is the product of a sustained decade-long research project (Becker et al. 2005). In the case of Lake Zurich, the paleoseismic research drew upon the results of earlier lake investigations (e.g. Hsü and Kelts 1970, 1984; Kelts and Hsü 1980; Siegenthaler et al. 1987).

\section{PALEOSEISMIC STUDIES OF LAKES IN EASTERN NORTH AMERICA}

A number of SAP studies in eastern North America report subaqueous mass movement deposits that are attributed to seismic shaking. These studies were located within or close to zones of concentrated historical seismicity in southern and southwestern Quebec that occur within a reactivated Iapetan rift system and along a Cretaceous hotspot trace (see Adams and Basham 1989, 1991). Important early work using SAP surveys was published by Shilts (1984) and Shilts and Clague (1992). Shilts (1984) presents selected examples of different types of disturbances found in lake deposits, including slump deposits in Lac Tee, Quebec (Fig. 6b), which he attributed to the historic AD 1935 Timiskaming earthquake (M 6.2). Shilts and Clague (1992) demonstrate the utility of SAP surveys for detecting "seismically induced deformation and mass transport" in lakes, and they provide a framework for interpreting a seismic trigger for such features. Their examples include mass movements considered to be triggered by the historic 1935 Timiskaming earthquake in lakes Tee, Kipawa and Timiskaming, Ontario - Quebec (Fig. 6b).
Following a preliminary interpretation by Shilts et al. (1989), Shilts et al. (1992) determined that the central basin of Lac Témiscouata, Quebec (Fig. 6b), was "modified at least three times by major mass-transport sedimentation events" during the postglacial period. Similar, but less extensive, deposits were found in nearby Grand lac Squatec (Fig. 6b). The mass-transport events were interpreted to have been triggered by 'seismic shocks' originating from local earthquakes rather than from the more distant Charlevoix - Kamouraska Seismic Zone (CKMZ) $90-100 \mathrm{~km}$ away. These interesting results, however, lack chronology, precluding the correlation of the major mass movement events between the two lake basins, which would strengthen the seismic trigger hypothesis. The lack of chronology also prevents correlation of the youngest stratigraphic mass-transport event to the strong AD 1663 Charlevoix earthquake (M $7.2 \pm 0.2$; Locat 2011), which might support or reject the interpretation of a local seismic trigger.

Doig $(1986,1990,1991,1998$ a) interpreted the occurrence of past earthquakes based on the presence of thin, concentrated silt layers, some overlain by a bed of 'chaotic' gyttja, contained in shallow cores up to $1.5 \mathrm{~m}$ long. Doig (1990) reported up to 22 silt layers in cores from Lac Tadoussac, Quebec (Fig. 6b), that were interpreted to represent earthquakes occurring over the past 2300 years within the CKMZ. The youngest five layers are attributed to historic earthquakes occurring between AD 1634 and 1925. Doig (1990) inferred the magnitude of the prehistoric earthquakes based on layer thickness and the temporal pattern of earthquake activity over the past 2300 years. In Lac Tee, Quebec, two well-defined silt layers were encountered in cores, one attributed to the $\mathrm{AD}$ 1935 M 6.2 Timiskaming earthquake and a deeper one to an older earthquake estimated to have occurred $\sim 1500$ years ago. Doig (1998a) reported one to three well-defined silt layers in cores recovered from three lakes in the Saguenay area, Quebec (Lac Jacques-Cartier, Lac Eternité and Petit lac Ha! Ha!; Fig. $6 \mathrm{~b})$ that he interpreted to be the product of local seismicity rather than earthquakes in the more distant CKMZ. Chronology, however, is problematic in all of Doig's studies, as it is extrapolated from modern sedimentation rates (based on late $20^{\text {th }}$ century ${ }^{137} \mathrm{Cs}$ concentrations) to periods extending up to several millennia. Thus, the estimated 1500, 2300 and 3000 year timespans of Doig's studies and the ages assigned to the deeper silt layers have considerable uncertainty and must be regarded as approximations at best.

Ouellet (1997) summarized a regional lake study that conducted SAP surveys in 34 lakes in southern Quebec, some of which were cored, to investigate the spatial distribution of 
lake-sediment disturbances. Lakes containing multiple slumps, assessed by finding one slump for at least every two SAP profile legs, within the postglacial lacustrine deposits were found to be 'very common' within $100 \mathrm{~km}$ of the CKMZ. Thus, the pattern of slumping correlates well with modern regional seismicity and was attributed to seismic shaking from the CKMZ. Ouellet (1997) estimated a minimum trigger threshold for the slumping, based on the distribution of lakes containing slumps and the modern seismicity of the region. He also concluded that the seismicity of the CKMZ has occurred within the same general area throughout the postglacial period. However, the lack of chronology for the slumping precluded any conclusions being drawn concerning the temporal pattern of seismic activity.

A relatively long stratigraphic record from Lac Matamek, near Sept-Iles, Quebec (Fig. 6b), is reported by Ouellet and Seguin (1999), based on a $10.3 \mathrm{~m}$-long core. They attributed several acoustically transparent silt layers in the lacustrine deposits to "several earthquakes" over the past 7000 years. Unfortunately, these results are presented only briefly in a conference abstract; nevertheless, they are taken from the longest core reported in any paleoseismic lake study in eastern Canada.

Doughty et al. (2010) conducted a detailed SAP survey of Lac Kipawa, Quebec (Fig. 6b), to map the distribution of slumps that had been identified previously by Shilts and Clague (1992). Widespread slump deposits were recognized and interpreted to be "very young." The slumping was inferred to be the product of the historic AD 1935 Timiskaming earthquake, in agreement with Shilts and Clague (1992). This earthquake was interpreted to be the "largest postglacial seismic event of the last $\sim 8000$ years in the Kipawa area," as no older slump deposits were recognized within the basin.

Normandeau et al. (2013) conducted SAP and multibeam bathymetric surveys, and collected shallow cores $(0.6$ to $1.5 \mathrm{~m}$ long) in an investigation of the late Quaternary deposits in Lac St.-Joseph, Quebec (Fig. 6b). They identified sets of mass movement deposits, which were inferred to be seismically triggered, in both the late-glacial and the late Holocene portions of the stratigraphy. The chronology of the deposits was based on the regional sequence of environmental change and a single late Holocene radiocarbon age, derived from a bulk organic sample. They concluded that their younger seismic event predates the AD 1663 Charlevoix earthquake, based on the radiocarbon age, and consider that the event was the product of a local earthquake rather one than from the CKSZ.

Adams $(1982,1989,1996)$ recognized zones of disturbed varves, ranging from a few millimetres to $4 \mathrm{~m}$ thick, in exposures of early Holocene glaciolacustrine deposits of glacial Lake Ojibwa-Barlow in northeastern Ontario - northwestern Quebec. An existing regional varve chronology (Antevs 1925, 1928) allowed synchronous deformation to be identified between localities. In one case, the deformation extends over a $12000 \mathrm{~km}^{2}$ area and displays a crude concentric pattern, with the thicker contorted beds located in the central area. Adams interpreted these features to be stratigraphic evidence of paleoearthquake shaking during deglaciation.

Several conclusions can be drawn from the eastern Canadian paleoseismic lake basin investigations. None of the studies has a detailed, well-dated, paleoseismic record, although this was not the identified goal per se of most of the studies. The lack of solid chronologies limits some of the seismic inferences to being suppositions. An obvious factor contributing to the chronology problem is that only one study (Ouellet and Seguin 1999) collected core longer than $1-2 \mathrm{~m}$, and a number of the studies did not collect core. The recent studies of Doughty et al. (2010) and Normandeau et al. (2013) are based on high-density SAP surveys, but only the latter includes a three-dimensional stratigraphy. Paleoseismic research on eastern Canadian lake basins has lacked a sustained focus that would drive the collection of detailed data within a specific area of what is a large region containing a great number of lakes. Instead, the studies have occurred relatively sporadically both in time and space over a period of several decades, although the Timiskaming - Kipawa area has attracted renewed research interest (see Shilts and Clague 1992; Doughty et al. 2010, 2013). Given the documented occurrence of disturbed deposits in a number of eastern Canadian lakes within an area of historical seismicity, the eastern Canadian earthquake catalogue could be augmented significantly by applying the detailed seismo- and chrono-stratigraphic methods exemplified in the Swiss paleoseismic lake studies.

\section{NEGATIVE EVIDENCE OF PALEOSEISMICITY}

Negative evidence of paleoseismicity can be important in assessing prehistorical earthquakes (Obermeirer 2009). The concept of negative evidence requires soundly demonstrating that there is a lack of evidence of paleoseismicity within a given area. A lack of knowledge, however, does not constitute negative evidence (Musson et al. 2001). Establishing a lack-ofevidence criterion requires applying a method for investigating paleoseismology that is appropriate to the area of interest and would be expected to yield such evidence, if it exists.

In the eastern Canada setting, there is a strong correlation between the presence of widespread subaqueous slumping in postglacial lacustrine deposits and areas that have experienced historic earthquakes (Shilts and Clague 1992; Shilts et al. 1992; Ouellet 1997). The absence of disturbed deposits in a lake basin(s) thus can provide negative evidence of paleoseismicity, if deposits exist that would be susceptible to seismicallyinduced disturbance and if it can be reasonably inferred that this susceptibility has persisted for thousands of years (McCalpin and Nelson 2009). The focus of investigation, however, is on identifying, dating, and assessing the origin of potentially seismically disturbed deposits that may be present in a given lake basin, as opposed to seeking negative evidence per se. The local minimum level of prehistoric ground shaking that can be inferred is the threshold of formation of smallscale soft-sediment deformation and liquefaction features in lake deposits, which occurs between intensities of VI and VII (EMS), or $\mathrm{M}_{\mathrm{w}} 5.0$ - 5.5 (Obermeirer 1996, 2009; Monecke et al. 2004). Negative evidence as a constraint for the occurrence of greater-than-threshold shaking is only applicable over the time span of the sedimentary record that lacks seismicallyinduced disturbed deposits.

The presence of widespread, medium- to large-scale, mass movements and turbidite deposits can be determined from a relatively dense SAP survey within a given lake basin. A broader pattern of widespread disturbed deposits can be recognized by surveying multiple basins within an area of interest (e.g. 
Ouellet 1997). The apparent absence of mass movement or turbidite deposits in SAP returns, however, does not constitute negative evidence of paleoseismicity, since small-scale disturbed deposits might fall below the threshold of resolution of SAP returns.

Establishing the presence or absence of small-scale disturbed deposits within a lake basin requires recovering and analyzing core. These should be collected from areas within a basin that are favourable for the formation or accumulation of disturbed deposits. Based on the results of Doig (1986), Monecke et al. (2004) and Strasser et al. (2013), favourable areas are the deeper, steep-sided portions of a lake basin having a reasonably-sized contributing watershed. The number of cores needed to establish negative evidence would have to be determined from the characteristics of the lake within a specific study area. Negative evidence should be accrued from a paleoseismic investigation of a number of selected lake basins within an area of interest. The results from other approaches to investigating paleoseismicity, as appropriate to the area of interest, must also be considered to establish negative evidence.

\section{SUMMARY AND CONCLUSIONS}

Application of a detailed seismo- and chrono-stratigraphic approach to the paleoseismic investigation of eastern Canadian lake basins could significantly augment the regional earthquake catalogue, as demonstrated by the earthquake catalogue for central Switzerland, which spans 16000 years and is based primarily on the study of lake deposits.

A high-density SAP survey in combination with core recovery and analysis allow the establishment of the seismoand chrono-stratigraphy of lake deposits. Event layers comprising one or more disturbed deposits can be identified, mapped and dated. Maps depicting the extent and type of disturbed deposits common to each event layer allow the layers to be readily compared and the possibility of a seismic triggering mechanism to be assessed.

The widespread presence of mass movement and turbidite deposits at a common stratigraphic level within a lake basin is characteristic of moderately strong (or greater) earthquake shaking. Smaller-scale disturbed deposits (disturbed/contorted sediments and liquefaction structures) can be formed by lesser seismic shaking. The possibility of non-seismic mechanisms needs to be considered before a seismically induced trigger is interpreted.

Investigation of several lakes within a region allows a common dated event layer to be correlated and compared between the basins, providing strong corroboration for the interpretation of a seismic trigger. It also allows the pattern of a regional paleoearthquake signature to be reconstructed for an evaluation of shaking intensity.

The absence of seismically-induced disturbed deposits in SAP profiles and in recovered cores within a given area can contribute to establishing negative evidence of paleoseismicity. Deposits susceptible to seismically-induced disturbance, however, must be present in the basin and this susceptibility to disturbance must have persisted for thousands of years. Results from other types of paleoseismic investigations, as appropriate to the area of interest, must also be considered in order to establish negative evidence of paleoseismicity.

\section{ACKNOWLEDGEMENTS}

Comments from John Adams, Jim Hunter and Mike Lewis, and journal reviewers John Clague and Ian Spooner are sincerely appreciated. Sam Alpay kindly provided the sub-bottom profile used in Figure 1. Katrin Monecke and Michael Strasser kindly gave permission to reproduce figures 3 and 4, and 5 and 7, respectively. This paper was written with support from the Public Safety Geoscience Program, Earth Sciences Sector, Natural Resources Canada and represents ESS Contribution 20140025.

\section{REFERENCES}

Adams, J., 1982, Deformed lake sediments record prehistoric earthquakes during the deglaciation of the Canadian Shield (abstract): EOS, Transactions, American Geophysical Union, v. 63, p. 436.

Adams, J., 1989, Postglacial faulting in eastern Canada: Nature, origin and seismic hazard implications: Tectonophysics, v. 163, p. 323-331, http://dx.doi.org/ 10.1016/0040-1951(89)90267-9.

Adams, J., 1990, Paleoseismicity of the Cascadia Subduction Zone: Evidence from turbidites off the Oregon-Washington Margin: Tectonics, v. 9, p. 569-583, http://dx.doi.org/10.1029/TC009i004p00569.

Adams, J., 1996, Paleoseismology in Canada: A dozen years of progress: Journal of Geophysical Research, v. 101, p. 6193-6207, http://dx.doi.org/10.1029/ 95JB01817.

Adams, J., and Basham, P., 1989, The seismicity and seismotectonics of Canada east of the Cordillera: Geoscience Canada, v. 16, p. 3-16.

Adams, J., and Basham, P., 1991, The seismicity and seismotectonics of eastern Canada, in Slemmons, D.B., Engdahl, E.R., Zoback, M.D., and Blackwell, D.D., eds., Neotectonics of North America: Geological Society of America, Decade Map, v. 1, p. 261-276

Adams, J., Wetmiller, R.J., Hasegawa, H.S., and Drysdale, J., 1991, The first surface faulting from a historical intraplate earthquake in North America: Nature, v. 352, p. 617-619, http://dx.doi.org/10.1038/352617a0

Anselmetti, F.S., Ariztegui, D., De Batist, M., Catalina Gebhardt, A., Haberzettl, T., Niessen, F., Ohlendorf, C., and Zolitschka, B., 2009, Environmental history of southern Patagonia unravelled by the seismic stratigraphy of Laguna Potrok Aike: Sedimentology, v. 56, p. 873-892, http://dx.doi.org/10.1111/j.13653091.2008.01002.x.

Antevs, E., 1925, Retreat of the last ice-sheet in eastern Canada: Geological Survey of Canada, Memoir 146, 138 p.

Antevs, E., 1928, The last glaciation with reference to the retreat in northeastern North America: American Geographical Society, Research Series No. 17, 262 p.

Appleby, P.G., 2001, Chronostratigraphic techniques in recent sediments, in Last, W.M., and Smol, J.P., eds., Tracking environmental change using lake sediments. Volume 1. Basin analysis, coring, and chronological techniques: Kluwer Academic Publishers, Dordrecht, p. 171-203.

Audemard M., F.A., and Michetti, A.M., 2011, Geological criteria for evaluating seismicity revealed: Forty years of paleoseismic investigations and the natural records of past earthquakes, in Audemard M., F.A., Michetti, A.M., and McCalpin, J.P., eds., Geological criteria for evaluating seismicity revealed: Forty years of paleoseismic investigations and the natural records of past earthquakes: Geological Society of America Special Papers, v. 479, p. 1-21, http://dx.doi.org/10.1130/2011.2479(00).

Beck, C., 2009, Late Quaternary lacustrine paleo-seismic archives in north-western Alps: Examples of earthquake-origin assessment of sedimentary disturbances: Earth-Science Reviews, v. 96, p. 327-344, http://dx.doi.org/10.1016/ j.earscirev.2009.07.005

Beck, C., 2011, Lake sediments as late Quaternary paleoseismic archives: Examples in the northwestern Alps and clues for earthquake-origin assessment of sedimentary disturbances, in Audemard M., F.A., Michetti, A.M., and McCalpin, J.P., eds., Geological criteria for evaluating seismicity revealed: Forty years of paleoseismic investigations and the natural records of past earthquakes: Geological Society of America Special Papers, v. 479, p. 159-179, http://dx.doi.org/ 10.1130/2011.2479(07).

Beck, C., Manalt, F., Chapron, E., Van Rensbergen, P., and De Batist, M., 1996, Enhanced seismicity in the early post-glacial period: Evidence from the postwürm sediments of Lake Annecy, northwestern Alps: Journal of Geodynamics, v. 22, p. 155-171, http://dx.doi.org/10.1016/0264-3707(96)00001-4.

Becker, A., Ferry, M., Monecke, K., Schnellmann, M., and Giardini, D., 2005, Multiarchive paleoseismic record of late Pleistocene and Holocene strong earthquakes in Switzerland: Tectonophysics, v. 400, p. 153-177, http://dx.doi.org/ 10.1016/j.tecto.2005.03.001.

Bennett, K.D., and Willis, K.J., 2001, Pollen, in Smol, J.P., Birks, H.J.B., and Last, W.M., eds., Tracking environmental change using lake sediments. Volume 3: Terrestrial, algal, and siliceous indicators: Kluwer Academic Publishers, Dordrecht, p. 5-32.

Bertrand, S., Charlet, F., Chapron, E., Fagel, N., and De Batist, M., 2008, Reconstruction of the Holocene seismotectonic activity of the Southern Andes from 
seismites recorded in Lago Icalma, Chile, $39^{\circ} \mathrm{S}$ : Palaeogeography, Palaeoclimatology, Palaeoecology, v. 259, p. 301-322, http://dx.doi.org/10.1016/ j.palaeo.2007.10.013.

Björck, S., and Wohlfarth, B., 2001, ${ }^{14} \mathrm{C}$ chronostratigraphic techniques in paleolimnology, in Last, W.M., and Smol, J.P., eds., Tracking environmental change using lake sediments. Volume 1. Basin analysis, coring, and chronological techniques: Kluwer Academic Publishers, Dordrecht, p. 205-245.

Blais-Stevens, A., and Clague, J.J., 2001, Paleoseismic signature in late Holocene sediment cores from Saanich Inlet, British Columbia: Marine Geology, v. 175, p 131-148, http://dx.doi.org/10.1016/S0025-3227(01)00132-3.

Blais-Stevens, A., Rogers, G.C., and Clague, J.J., 2011, A revised earthquake chronology for the last 4,000 years inferred from varve-bounded debris-flow deposits beneath an inlet near Victoria, British Columbia: Bulletin of the Seismological Society of America, v. 101, p. 1-12, http://dx.doi.org/10.1785/0120090360.

Bowman, D., Korjenkov, A., and Porat, N., 2004, Late-Pleistocene seismites from Lake Issyk-Kul, the Tien Shan range, Kyrghyzstan: Sedimentary Geology, v. 163, p. 211-228, http://dx.doi.org/10.1016/S0037-0738(03)00194-5

Carrillo, E., Audemard M., F.A., Beck, C., Cousin, M., Jouanne, F., Cano, V., Castilla, R., Melo, L., and Villemin, T., 2006, A Late Pleistocene-Holocene natural seismograph along the Boconó Fault (Mérida Andes, Venezuela): The morainedammed Los Zerpa paleo-lake: Bulletin de la Société Géologique de France, v. 177, p. 3-17, http://dx.doi.org/10.2113/177.1.3.

Chapron, E., Beck, C., Pourchet, M., and Deconinck, J.-F., 1999, 1822 earthquaketriggered homogenite in Lake Le Bourget (NW Alps): Terra Nova, v. 11, p. 86-92, http://dx.doi.org/10.1046/j.1365-3121.1999.00230.x.

Clague, J.J., Shilts, W.W., and Linden, R.H., 1989, Application of subbottom profiling to assessing seismic risk on Vancouver Island, British Columbia: Current Research, Part E, Geological Survey of Canada, Paper 89-1E, p. 237-242.

Doig, R., 1986, A method for determining the frequency of large-magnitude earthquakes using lake sediments: Canadian Journal of Earth Sciences, v. 23, p. 930-937, http://dx.doi.org/10.1139/e86-094.

Doig, R., 1990, 2300 yr history of seismicity from silting events in Lake Tadoussac, Charlevoix, Quebec: Geology, v. 18, p. 820-823, http://dx.doi.org/10.1130/ 0091-7613(1990)018<0820:YHOSFS > 2.3.CO;2.

Doig, R., 1991, Effects of strong seismic shaking in lake sediments, and earthquake recurrence interval, Témiscaming, Quebec: Canadian Journal of Earth Sciences, v. 28 , p. 1349-1352, http://dx.doi.org/10.1139/e91-118.

Doig, R., 1998, 3000-year paleoseismological record from the region of the 1988 Saguenay, Quebec, earthquake: Bulletin of the Seismological Society of America, v. 88, p. 1198-1203.

Doughty, M., Eyles, N., and Daurio, L., 2010, Earthquake-triggered slumps (1935 Timiskaming M6.2) in Lake Kipawa, Western Quebec Seismic Zone, Canada: Sedimentary Geology, v. 228, p. 113-118, http://dx.doi.org/10.1016/j.sedgeo.2010.04.003

Doughty, M., Eyles, N., and Eyles, C., 2013, High-resolution seismic reflection profiling of neotectonic faults in Lake Timiskaming, Timiskaming Graben, Ontario-Quebec, Canada: Sedimentology, v. 60, p. 983-1006, http://dx.doi.org/10.1111/sed.12002.

Dyke, A.S., Moore, A., and Roberston, L., 2003, Deglaciation of North America: Geological Survey of Canada, Open File 1574, 2 Sheets, 1 CD-ROM, http://dx.doi.org/10.4095/214399.

Enkin, R.J., Dallimore, A., Baker, J., Southon, J.R., and Ivanochko, T., 2013, A new high-resolution radiocarbon Bayesian age model of the Holocene and Late Pleistocene from core MD02-2494 and others, Effingham Inlet, British Columbia, Canada; with an application to the paleoseismic event chronology of the Cascadia Subduction Zone: Canadian Journal of Earth Sciences, v. 50, p. 746-760, http://dx.doi.org/10.1139/cjes-2012-0150.

Glew, J.R., Smol, J.P., and Last, W.M., 2001, Sediment core collection and extrusion, in Last, W.M., and Smol, J.P., eds., Tracking environmental change using lake sediments. Volume 1: Basin analysis, coring, and chronology techniques: Kluwer Academic Publishers, Dordrecht, p. 73-105.

Hermanns, R.L., and Niedermann, S., 2011, Late Pleistocene -early Holocene paleoseismicity deduced from lake sediment deformation and coeval landsliding in the Calchaquíes valleys, NW Argentina, in Audemard M., F.A., Michetti, A.M. and McCalpin, J.P., eds., Geological criteria for evaluating seismicity revealed: Forty years of paleoseismic investigations and the natural records of past earthquakes: Geological Society of America Special Papers, v. 479, p. 181-194 http://dx.doi.org/10.1130/2011.2479(08)

Hsü, K.J., and Kelts, K.R., 1970, Seismic investigation of Lake Zurich: Part II Geol ogy: Eclogae Geologicae Helvetiae, v. 63, p. 525-538.

Hsü, K.J., and Kelts, K.R., eds., 1984, Quaternary geology of Lake Zurich: An interdisciplinary investigation by deep-lake drilling: Contributions to Sedimentology, v. $13,471 \mathrm{p}$

Inouchi, Y., Kinugasa, Y., Kumon, F., Nakano, S., Yasumatsu, S., and Shiki, T., 1996 Turbidites as records of intense palaeoearthquakes in Lake Biwa, Japan: Sedimentary Geology, v. 104, p. 117-125, http://dx.doi.org/10.1016/0037-
0738(95)00124-7.

Jibson, R.W., 2009, Using landslides for paleoseismic analysis, in McCalpin, J.P., ed., Paleoseismology, 2nd edition, International Geophysics, v. 95, p. 565-601, http://dx.doi.org/10.1016/S0074-6142(09)95008-2.

Karlin, R.E., and Abella, S.E.B., 1996, A history of Pacific Northwest earthquakes recorded in Holocene sediments from Lake Washington: Journal of Geophysical Research, v. 101, p. 6137-6150, http://dx.doi.org/10.1029/95JB01626.

Karlin, R.E., Holmes, M., Abella, S.E.B., and Sylwester, R., 2004, Holocene landslides and a 3500-year record of Pacific Northwest earthquakes from sediments in Lake Washington: Geological Society of America Bulletin, v. 116, p. 94-108, http://dx.doi.org/10.1130/B25158.1.

Kelts, K.R., and Hsü, K.J., 1980, Resedimented facies of 1875 Horgen slumps in Lake Zurich and a process model of longitudinal transport of turbidity currents: Eclogae Geologicae Helvetiae, v. 73, p. 271-281.

King, K., and Peck, J., 2001, Use of paleomagnetism in studies of lake sediments, in Last, W.M. and Smol, J.P., eds., Tracking environmental change using lake sediments. Volume 1. Basin analysis, coring, and chronological techniques: Kluwer Academic Publishers, Dordrecht, p. 371-389.

Lamontagne, M., Halchuk, S., Cassidy, J.F., and Rogers, G.C., 2008, Significant Canadian earthquakes of the period 1600-2006: Seismological Research Letters: v. 79, p. 211-223, http://dx.doi.org/10.1785/gssrl.79.2.211.

Lamoureux, S., 2001, Varve chronology techniques, in Last, W.M., and Smol, J.P., eds., Tracking environmental change using lake sediments. Volume 1. Basin analysis, coring, and chronological techniques: Kluwer Academic Publishers, Dordrecht, p. 247-259.

Leroy, S.A.G., and Coleman, S.M., 2001, Core and drilling equipment and procedures for recovery of long lacustrine sequences, in Last, W.M., and Smol, J.P., eds., Tracking environmental change using lake sediments. Volume 1: Basin analysis, coring, and chronology techniques: Kluwer Academic Publishers, Dordrecht, p. 107-135.

Locat, J., 2011, La localisation et la magnitude du séisme du 5 février 1663 (Charlevoix) revues à l'aide des mouvements de terrain: Canadian Geotechnical Journal, v. 48, p. 1266-1286, http://dx.doi.org/10.1139/t11-029.

Lucchi, F.R., 1995, Sedimentological indicators of paleoseismicity, in Serva, L., and Slemmons, D.B., eds., Perspectives in paleoseismology: Association of Engineering Geologists, Special Publication 6, p. 7-17.

Maloney, J.M., Noble, P.J., Driscoll, N.W., Kent, G.M., Smith, S.B., Schmauder, G.C., Babcock, J.M., Baskin, R.L., Karlin, R., Kell, A.M., Seitz, G.G., Zimmerman, S., and Kleppe, J.A., 2013, Paleoseismic history of the Fallen Leaf segment of the West Tahoe-Dollar Point Fault reconstructed from slide deposits in the Lake Tahoe Basin, California-Nevada: Geosphere, v. 9, p. 1065-1090, http://dx.doi.org/10.1130/GES00877.1.

McCalpin, J.P., and Nelson, A.R., 2009, Introduction to paleoseismicity, in McCalpin, J.P., ed., Paleoseismology, 2nd edition: International Geophysics, v. 95, p. 1-27.

Micallef, A., 2011, Marine geomorphology; geomorphological mapping and the study of submarine landslides, in Smith, M.J., Paron, P., and Griffiths, J.S., eds., Geomorphological mapping: Methods and Applications: Developments in Earth Surface Processes, v. 15, p. 377-395, http://dx.doi.org/10.1016/B978-0444-53446-0.00013-6.

Moernaut, J., De Batist, M., Charlet, F., Heirman, K., Chapron, E., Pino, M., Brümmer, R., and Urrutia, R., 2007, Giant earthquakes in South-Central Chile revealed by Holocene mass-wasting events in Lake Puyehue: Sedimentary Geology, v. 195, p. 239-256, http://dx.doi.org/10.1016/j.sedgeo.2006.08.005.

Moernaut, J., De Batist, M., Heirman, K., Van Daele, M., Pino, M., Brümmer, R., and Urrutia, R., 2009, Fluidization of buried mass-wasting deposits in lake sediments and its relevance for paleoseismology: Results from a reflection seismic study of lakes Villarrica and Calafquén (South-Central Chile): Sedimentary Geology, v. 213, p. 121-135, http://dx.doi.org/10.1016/j.sedgeo.2008.12.002.

Monecke, K., Anselmetti, F.S., Becker, A., Sturm, M., and Giardini, D., 2004, The record of historic earthquakes in lake sediments of Central Switzerland: Tectonophysics, v. 394, p. 21-40, http://dx.doi.org/10.1016/j.tecto.2004. 07.053 .

Monecke, K., Anselmetti, F.S., Becker, A., Schnellmann, M., Sturm, M., and Giardini, D., 2006, Earthquake-induced deformation structures in lake deposits: A Late Pleistocene to Holocene paleoseismic record for Central Switzerland: Eclogae Geologicae Helvetiae, v. 99, p. 343-362, http://dx.doi.org/10.1007/ s00015-006-1193-x.

Morey, A.E., Goldfinger, C., Briles, C.E., Gavin, D.G., Colombaroli, D., and Kusler, J.E., 2013, Are great Cascadia earthquakes recorded in the sedimentary records from small forearc lakes?: Natural Hazards and Earth Systems Science, v. 13, p. 2441-2463, http://dx.doi.org/10.5194/nhess-13-2441-2013.

Mörner, N.-A., 2003, Paleoseismicity of Sweden: a novel paradigm: A contribution to INQUA from its Sub-commission on Paleoseismicity, Paleogeophysics \& Geodynamics, Stockholm University, Stockholm, 320 p.

Mörner, N.-A., 2005, An interpretation and catalogue of paleoseismicity in Sweden: Tectonophysics, v. 408 , p. 265-307, http://dx.doi.org/10.1016/ 
j.tecto.2005.05.039.

Mörner, N.-A., 2009, Late Holocene earthquake geology in Sweden, in Reicherter, K., Michetti, A.M., and Silva, P.G., eds., Paleoseismology: Historical and Prehistorical Records of Earthquake Ground Effects for Seismic Hazard Assessment: Geological Society, London, Special Publications, v. 316, p. 179-188, http://dx.doi.org/10.1144/SP316.11.

Musson, R.M.W., Mikkelsen, T., and Ziska, H., 2001, Historical seismicity of the Faroe Islands: Annals of Geophysics: v. 44, p. 1031-1047.

Nomade, J., Chapron, E., Desmet, M., Reyss, J.-L., Arnaud, F., and Lignier, V., 2005 Reconstructing historical seismicity from lake sediments (Lake Laffrey, Western Alps, France): Terra Nova, v. 17, p. 350-357, http://dx.doi.org/10.1111/j.13653121.2005.00620.x.

Normandeau, A., Lajeunesse, P., and Philibert, G., 2013, Late-Quaternary morphostratigraphy of Lake St-Joseph (southeastern Canadian Shield): Evolution from a semi-enclosed glacimarine basin to a postglacial lake: Sedimentary Geology, v. 295, p. 38-52, http://dx.doi.org/10.1016/j.sedgeo.2013.07.005.

Obermeirer, S.F., 1996, Use of liquefaction-induced features for paleoseismic analysis - An overview of how seismic liquefaction features can be distinguished from other features and how their regional distribution and properties of source sediment can be used to infer the location and strength of Holocene paleo-earthquakes: Engineering Geology, v. 44, p. 1-76, http://dx.doi.org/ 10.1016/S0013-7952(96)00040-3.

Obermeirer, S.F., 2009, Using liquefaction-induced and other soft-sediment features for paleoseismic analysis, in McCalpin, J.P., ed., Paleoseismology, 2nd edition: International Geophysics, v. 95, p. 497-564, http://dx.doi.org/10.1016/S00746142(09)95007-0.

Ouellet, M., 1997, Lake sediments and Holocene seismic hazard assessment within the St. Lawrence Valley, Quebec: Geological Society of America Bulletin, v. 109, p. 631-642, http://dx.doi.org/10.1130/0016-7606(1997)109<0631:LSAHSH> 2.3.CO;2.

Ouellet, M., and Seguin, M.K., 1999, A possible 7000-year long record of paleoseismic activity from Lake Matamek sediments, Quebec, Canada (abstract): EOS, Transactions American Geophysical Union, v. 80, p. 737.

Owen, G., Moretti, M., and Alfaro, P., 2011, Recognising triggers for soft-sediment deformation: Current understanding and future directions: Sedimentary Geology, v. 235, p. 133-140, http://dx.doi.org/10.1016/j.sedgeo.2010.12.010.

Prior, D.B., Bornhold, B.D., and Johns, M.W., 1984, Depositional characteristics of a submarine debris flow: The Journal of Geology, v. 92, p. 707-727, http://dx.doi.org/10.1086/628907.

Schnellmann, M., Anselmetti, F.S., Giardini, D., McKenzie, J.A., and Ward, S.N., 2002, Prehistoric earthquake history revealed by lacustrine slump deposits: Geology, v. 30, p. 1131-1134, http://dx.doi.org/10.1130/0091-7613(2002)030 $<1131$ :PEHRBL>2.0.CO;2.

Schnellmann, M., Anselmetti, F.S., Giardini, D., and McKenzie, J.A., 2006, 15,000 Years of mass-movement history in Lake Lucerne: Implications for seismic and tsunami hazards: Eclogae Geologicae Helvetiae, v. 99, p. 409-428, http://dx.doi.org/10.1007/s00015-006-1196-7.

Scholz, C.A., 2001, Applications of seismic sequence stratigraphy in lacustrine basins, in Last, W.M., and Smol, J.P., eds., Tracking environmental change using lake sediments. Volume 1. Basin analysis, coring, and chronological techniques: Kluwer Academic Publishers, Dordrecht, p.7-22.

Shiki, T., Kumon, F., Inouchi, Y., Kontani, Y., Sakamoto, T., Tateishi, M., Matsubara, H., and Fukuyama, K., 2000, Sedimentary features of the seismo-turbidites, Lake Biwa, Japan: Sedimentary Geology, v. 135, p. 37-50, http://dx.doi.org/10.1016/S0037-0738(00)00061-0.

Shilts, W.W., 1984, Sonar evidence of postglacial tectonic instability of the Canadian Shield and Appalachians: Current Research, Part A, Geological Survey of Canada, Paper 84-1A, p. 567-579.

Shilts, W.W., and Clague, J.J., 1992, Documentation of earthquake-induced disturbance of lake sediments using subbottom acoustic profiling: Canadian Journal of Earth Sciences, v. 29, p. 1018-1042, http://dx.doi.org/10.1139/e92-084.

Shilts, W.W., Blais, A., and Adams, A., 1989, Subbottom profiling of Quebec Appalachian lakes and its potential application to assessing seismic hazard: Current Research, Part B, Geological Survey of Canada, Paper 89-1B, p. 143-154.

Shilts, W.W., Rappol, M., and Blais, A., 1992, Evidence of late and postglacial seismic activity in the Témiscouata -Madawaska Valley, Quebec-New Brunswick, Canada: Canadian Journal of Earth Sciences, v. 29, p. 1043-1069, http://dx.doi.org/10.1139/e92-085.

Siegenthaler, C., Finger, W., Kelts, K., and Wang, S., 1987, Earthquake and seiche deposits in Lake Lucerne, Switzerland: Eclogae Geologicae Helvetiae, v. 80, p. 241-260.

Sims, J.D., 1973, Earthquake-induced structures in sediments of Van Norman Lake, San Fernando, California: Science, v. 182, p. 161-163, http://dx.doi.org/ 10.1126/science.182.4108.161.

Sims, J.D., 1975, Determining earthquake recurrence intervals from deformational structures in young lacustrine sediments: Tectonophysics, v. 29, p. 141-152, http://dx.doi.org/10.1016/0040-1951(75)90139-0.

St.-Onge, G., Mulder, T., Piper, D.J.W., Hillaire-Marcel, C., and Stoner, J.S., 2004, Earthquake and flood-induced turbidites in the Saguenay Fjord (Québec): A Holocene paleoseismicity record: Quaternary Science Reviews, v. 23, p. 283-294, http://dx.doi.org/10.1016/j.quascirev.2003.03.001.

Strasser, M., Anselmetti, F.S., Fäh, D., Giardini, D., and Schnellmann, M., 2006, Magnitudes and source areas of large prehistoric northern Alpine earthquakes revealed by slope failures in lakes: Geology, v. 34, p. 1005-1008, http://dx.doi.org/10.1130/G22784A.1.

Strasser, M., Monecke, K., Schnellmann, M., and Anselmetti, F.S., 2013, Lake sediments as natural seismographs: A compiled record of Late Quaternary earthquakes in Central Switzerland and its implication for Alpine deformation: Sedimentology, v. 60, p. 319-341, http://dx.doi.org/10.1111/sed.12003.

Syvitski, J.P.M., and Schafer, C.T., 1996, Evidence for an earthquake-triggered basin collapse in Saguenay Fjord, Canada: Sedimentary Geology, v. 104, p. 127-153, http:/ /dx.doi.org/10.1016/0037-0738(95)00125-5

Turney, C.S.M., and Lowe, J.J., 2001, Tephrochronology, in Last, W.M., and Smol, J.P., eds., Tracking environmental change using lake sediments. Volume 1. Basin analysis, coring, and chronological techniques: Kluwer Academic Publishers, Dordrecht, p. 451-470.

Upton, P., and Osterberg, E.C., 2007, Paleoseismicity and mass movements interpreted from seismic-reflection data, Lake Tekapo, South Canterbury, New Zealand. Journal of Geology and Geophysics, v. 50, p. 343-356, http://dx.doi.org/10.1080/00288300709509841.

Wheeler, R.L., 2002, Distinguishing seismic from nonseismic soft-sediment structures: Criteria from seismic-hazard analysis, in Ettensohn, F.R., Rast, N., and Brett, C.E., eds., Ancient seismites: Geological Society of America Special Papers, v. 359, p. 1-11, http://dx.doi.org/10.1130/0-8137-2359-0.1.

\section{Received April 2014}

Accepted as revised October 2014

First published on the web December 2014 


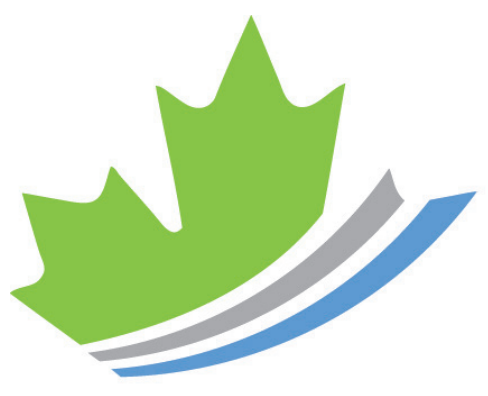

\section{GEOLOGICAL ASSOCIATION OF CANADA}

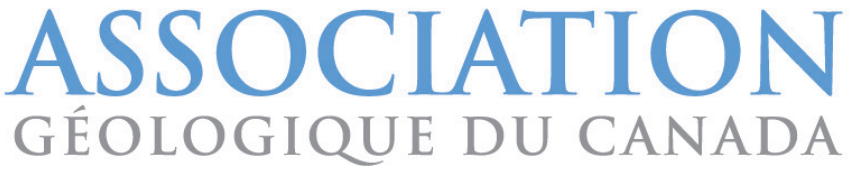

Books

Geology of Mineral Resources

Facies Models 4

Atlas of Alteration

Ore Mineral Atlas

Conferences

Whitehorse, June 1-3, 2016

whitehorse2016.ca

Kingston, ON, 2017

Vancouver, BC, 2018

JOURNAL

Geoscience Canada

\section{AWARDS}

Logan Medal

W.W. Hutchison Medal

E.R.Ward Neale Medal

J. Willis Ambrose Medal

Mary-Claire Ward Geoscience Award

Yves Fortier Earth Science Journalism Award

...and many more!

JOIN TODAY

7098647660

gac@mun.ca

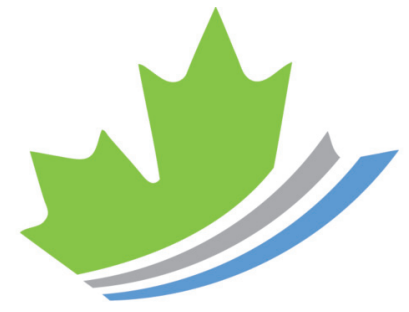

